\title{
The Dual Role of the Potyvirus P3 Protein of Turnip mosaic virus as a Symptom and Avirulence Determinant in Brassicas
}

\author{
Carol E. Jenner, ${ }^{1}$ Xiaowu Wang, ${ }^{2}$ Kenta Tomimura, ${ }^{3}$ Kazusato Ohshima, ${ }^{3}$ Fernando Ponz, ${ }^{2}$ and \\ John A. Walsh ${ }^{1}$ \\ ${ }^{1}$ Horticulture Research International, Wellesbourne, Warwick, CV35 9EF, U.K.; ${ }^{2}$ Departamento de Biotecnología, INIA, \\ Autopista A-6 km7, 28040 Madrid, Spain; ${ }^{3}$ Laboratory of Plant Virology, Faculty of Agriculture, Saga University, Saga 840- \\ 8502, Japan.
}

Submitted 10 March 2003. Accepted 28 May 2003.

Two isolates of the potyvirus Turnip mosaic virus (TuMV), UK 1 and CDN 1, differ both in their general symptoms on the susceptible propagation host Brassica juncea and in their ability to infect $B$. napus lines possessing a variety of dominant resistance genes. The isolate CDN 1 produces a more extreme mosaic in infected brassica leaves than UK 1 and is able to overcome the resistance genes TuRBO1, $T u R B 04$, and TuRB05. The resistance gene $T u R B 03$, in the $B$. napus line 22S, is effective against CDN 1 but not UK 1. The nucleic acid sequences of the UK 1 and CDN 1 isolates were $90 \%$ identical. The $C$-terminal half of the $P 3$ protein was identified as being responsible for the differences in symptoms in $B$. juncea. A single amino acid in the $P 3$ protein was found to be the avirulence determinant for $T u R B$ 03. Previous work already has identified the P3 as an avirulence determinant for TuRB 04. Our results increase the understanding of the basis of plant-virus recognition, show the importance of the potyviral P3 gene as a symptom determinant, and provide a role in planta for the poorly understood $\mathbf{P 3}$ protein in a normal infection cycle.

The small size of viral genomes is of interest to scientists wishing to understand the genetic basis of pathogenicity, whether toward plants or animals. To this end, much effort has been expended in sequencing viral genomes and in the analysis of mutants. In the case of the family Potyviridae, the largest family of viral plant pathogens (Shukla et al. 1994), full-length sequences in databases are now available for at least 36 different species. Sequences from viruses such as Potato virus $Y$ (PVY), Potato virus A, Wheat streak mosaic virus, and Plum pox virus (PPV) are particularly well represented. Data from such sources is useful for obtaining an understanding of the extent of variation within a species (Bateson et al. 1994; Glasa et al. 2002; Krause-Sakate et al. 2002). The identification of conserved motifs is useful in trying to understand common functions in viral life cycles (Shukla et al. 1991) (e.g., in the identi-

Corresponding author: Carol Jenner, Telephone: +44 1789 470382; Fax: +44 1789 470552; E-mail: carol.jenner@hri.ac.uk

Current address of X. Wang: Institute of Vegetables and Flowers, CAAS, Zhongguancun South Street No. 12, Beijing 100081, People's Republic of China.

Nucleotide sequence data reported is available in the GenBank database under accession number AY227024. fication of the cytoplasmic inclusion $[\mathrm{CI}]$ protein as an RNA helicase [Laín et al. 1990]). However, many aspects of potyviral protein function and pathogenicity remain unclear (Revers et al. 1999). The functions of the highly variable P1 and P3 proteins in particular are still rather enigmatic (UrcuquiInchima et al. 2001).

Turnip mosaic virus (TuMV) is a potyvirus with an unusually wide host range and is of particular importance to brassica crops (Shattuck 1992). In addition to the economic importance of TuMV, the TuMV-crucifer pathosystem is proving to be an excellent tool for studying plant-virus interactions at many different levels (Walsh and Jenner 2002). The extent of genetic variation in the species has been studied using coat protein (CP) sequences (Lehmann et al. 1997) or P1 and CP sequences (Ohshima et al. 2002). The pathogenic variation has been assessed using a range of different hosts, such as Brassica rapa (Hughes et al. 2002; Provvidenti 1980; Walsh et al. 2002) or $B$. napus (Hughes et al. 2002; Jenner and Walsh 1996; Walsh 1989).

The nonpersistent mode of transmission of potyviruses by aphids makes control of the disease by insecticides difficult (Tomlinson 1987) and control through plant resistance more attractive. Several resistance genes to TuMV have been identified, and four have been mapped: $T u$ in lettuce (Robbins et al. 1994) and TuRBO1, TuRBO2 (Walsh et al. 1999), and TuRBO3 (Hughes et al. in press) in B. napus. The TuMV determinants of avirulence for three Brassica resistance genes have been identified. These are the CI protein for TuRB01/TuRBO1b (Jenner et al. 2000; Walsh et al. 2002) and the P3 and CI proteins for TuRBO4 and TuRBO5 respectively (Jenner et al. 2002a). These discoveries have helped researchers to understand the basis of the TuMV pathotyping system (Jenner and Walsh 1996). Other potyviral avirulence determinants include the Pea seedborne mosaic virus (PSbMV) genome-linked protein (VPg) and P3 (Johansen et al. 2001; Keller et al. 1998), the PVY VPg and nuclear inclusion proteins (NIa and NIb) (Fellers et al. 2002; Masuta et al. 1999; Mestre et al. 2000), the Tobacco vein mottling virus VPg (Nicolas et al. 1997), and the Zucchini yellow mosaic virus $\mathrm{CP}$ (Ullah and Grumet 2002).

The resistance gene TuRBO3 was identified in B. napus line $22 \mathrm{~S}$, a line not among the original $B$. napus lines used to pathotype TuMV isolates (Walsh 1989). It is not effective against the TuMV isolate UK 1 , the type member of pathotype 1 . However, it is the first dominant resistance gene found to be active against the pathogenic isolate CDN 1, the type member of pathotype 4 and, as such, is of potential interest for breeding lines. 
In this article, we report the construction of an infectious clone of the isolate CDN 1 and the identification of the viral avirulence determinant for TuRBO3. Viral chimeras between isolates UK 1 and CDN 1 also identified the region of the genome responsible for the characteristic strong mosaic symptoms induced by CDN 1 on susceptible brassica hosts.

\section{RESULTS}

Natural sequence diversity.

The TuMV isolates UK 1 and CDN 1 originated from $B$. napus plants from different continents. The degree of genetic differences underlying their differing pathogenic abilities was assessed by genome sequence comparison. The UK 1 cDNA clone (p35Tunos) and CDN 1 cDNA clone (pVIR95) were $89.9 \%$ identical at the nucleic acid level and $95.4 \%$ identical at the amino acid level. The least conserved proteins were the $6 \mathrm{~K} 2, \mathrm{P} 1$, and $\mathrm{P} 3$ proteins ( 83 to $90 \%$ identical). There were 10 nucleotide differences between the sequences of the CDN 1 cDNA clone (GenBank accession no. AY227024) and the CDN 1 virus (GenBank accession no. AB093610) (Tomimura et al. 2003). This level of difference is consistent with the accumu-

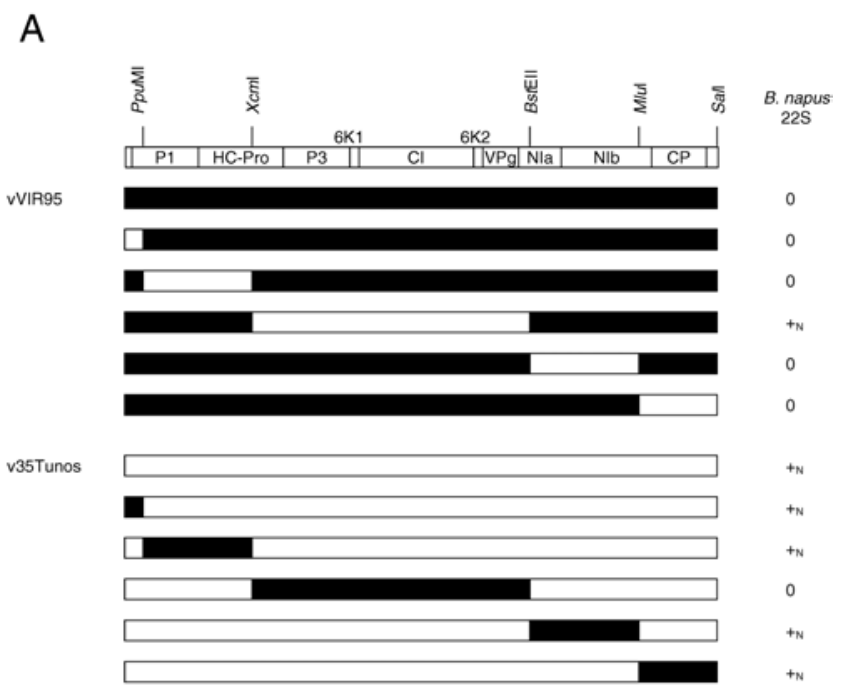

B

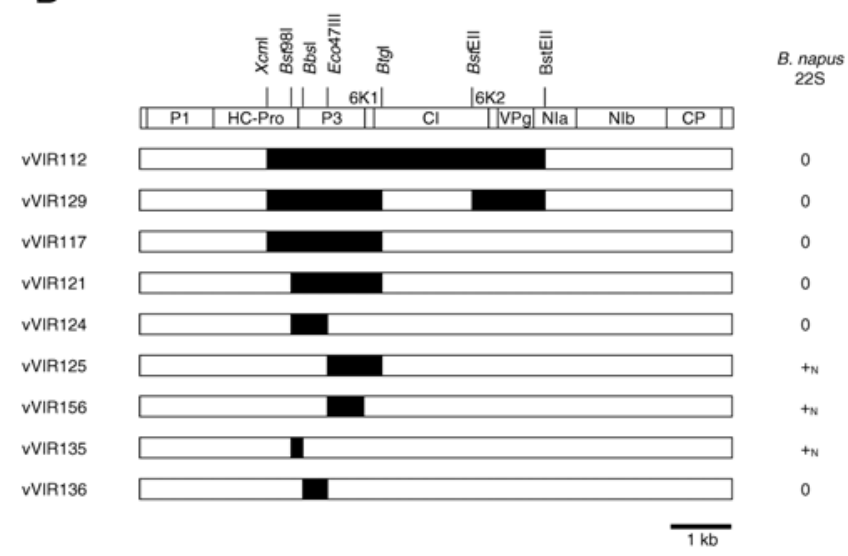

\footnotetext{
$\begin{array}{ll}0 & \text { no infection } \\ { }_{+N} & \text { systemic infection with necrotic symptoms }\end{array}$

CDN 1$$
\square \quad \text { UK } 1
$$

Fig. 1. Chimeric constructs of Turnip mosaic virus isolates CDN 1 and UK 1 and their abilities to infect Brassica napus line 22S. A, Reciprocal exchanges of all genomic sections. B, Identification of region encoding avirulence determinant of CDN 1. lation of mutations seen previously during subculture of UK 1 through $B$. juncea plants over several years in comparison to its infectious clone p35Tunos (Jenner et al. 2002a).

\section{Identification of an avirulence determinant in $\mathbf{P 3}$.}

In order to identify which viral gene was responsible for the differing phenotypes of UK 1 and CDN 1 on B. napus line 22S, reciprocal exchanges of all sections of the viral genome were made (Fig. 1A). Although UK 1 normally is able to infect line $22 \mathrm{~S}$, the introduction of the central 4.6-kb XcmI-BstEII fragment from CDN 1 was sufficient to block this ability. Conversely, the introduction of the UK 1 version of this fragment into $\mathrm{CDN} 1$ produced a construct able to infect line 22S (Fig. 1A). The smallest restriction fragment from CDN 1 conveying avirulence upon UK 1 was a $0.4-\mathrm{kb} B b s \mathrm{I}-E \operatorname{co} 47 \mathrm{III}$ fragment (in pVIR136; Fig. 1B). This introduced 68 nucleotide differences, but encoded only six amino acid differences, affecting P3 residues $65,73,118,144,148$, and 153. Site-directed mutagenesis (SDM) was performed to introduce each amino acid change individually into the UK 1 background. Two amino acid changes affected the phenotype of UK 1 on B. napus line 22S (Table 1). The alteration of $P 3 \mathrm{D} 148 \mathrm{~N}$ (using the nucleotide mutation $+2902 \mathrm{~A}>\mathrm{G}$ ) caused the severity of the necrotic infection to be lessened; the alteration of P3 I153F (using the nucleotide mutation $+2917 \mathrm{~A}>\mathrm{T}$ ) completely prevented any viral infection (Fig. 2).

The identification of the role of the $\mathrm{P} 3$ residue 153 in avirulence stimulated the construction via SDM of the reciprocal virus, a CDN 1 genome with the nucleotide mutation $+2917 \mathrm{~T}>\mathrm{A}$, thereby generating the UK 1 amino acid at this position, $P 3$ F153I. Virus derived from this construct was virulent and infected line $22 \mathrm{~S}$ with systemic mosaic symptoms (Fig. 2).

\section{Confirmation that the $\mathbf{P} 3$ is the avirulence determinant for TuRBO3.}

Lines $22 \mathrm{~S}$ and $\mathrm{N}-\mathrm{o}-1$ were crossed to produce the progenitors of the $\mathrm{B}_{1} \mathrm{~S}_{1}$ families. The former possesses TuRBO3 and is resistant to $\mathrm{CDN} 1$ (Hughes et al. in press). Line N-o-1 is susceptible to CDN 1 and is one of the parents of a well-characterized genetic mapping population (Sharpe et al. 1995). It possesses the resistance gene TuRBO1 and, therefore, is resistant to UK 1 (Walsh et al. 1999). However, the introduction of the mutation $+5570 \mathrm{~A}>\mathrm{G}$, causing the alteration $C I \mathrm{H} 630 \mathrm{R}$, into the UK 1 genome allows UK 1 to infect line N-o-1 (Jenner et al. 2000) and did not affect its ability to infect line $22 \mathrm{~S}$ (Fig. 2). Consequently, $20 \mathrm{~B}_{1} \mathrm{~S}_{1}$ families were inoculated separately with CDN $1 \pm P 3$ F153I, and with UK $1+C I$ H630R $\pm P 3$ I153F.

Six $B_{1} S_{1}$ families were uniformly susceptible to all of the viral constructs (Table 2) lacking any resistance to CDN 1. Fourteen families showed segregation for resistance to isolates possessing phenylalanine as residue 153 (CDN 1 or UK 1 CI H630R $P 3 \mathrm{I} 153 \mathrm{~F})$, but were uniformly susceptible to each of the viral constructs possessing isoleucine as $\mathrm{P} 3$ residue 153 (UK 1 CI H630R or CDN 1 P3 F153I). The ratio of families (14 with resistance: 6 totally susceptible) appears to be compatible with a hypothesis of two dominant resistance genes acting against CDN 1 (expected ratio 3:1). However, this may be an artifact of the small sample size. $B_{1}$ plants previously inoculated with CDN 1 segregated for resistance to susceptibility in a 1:1 ratio (57 and 56 plants, respectively; Hughes et al. in press), indicating the presence of not two but a single dominant resistance gene.

A $\chi^{2}$ test of homogeneity confirmed that the data from the segregating families could be pooled. A total of 78 plants were resistant and 34 susceptible to UK 1 CIH630R P3I153F, a ratio not significantly different from $3: 1(P=0.2)$, as expected for a 
single resistance gene. The ratio of resistant to susceptible plants (94 to 18, respectively) inoculated with CDN 1 differed from 3:1 $(P<0.05, P>0.01)$, and was compatible with a two-gene model (39:9, $P=0.5$ ). If two genes are present, they both were overcome by the introduction of the single amino acid change $P 3$ F153I into CDN 1. When the results of all inoculations using isolates with phenylalanine as residue 153 were combined, the segregation ratio was not significantly different from 3:1 (172 resistant, 52 susceptible, $P=0.5$ ). The segregating families probably are derived from $B_{1}$ plants that were heterozygous for a single dominant allele of a resistance gene. Hughes and associates (in press) identified and mapped the resistance to $\mathrm{CDN} 1$ in line $22 \mathrm{~S}$ to a single locus, namely TuRBO3.

The $20 \mathrm{~B}_{1} \mathrm{~S}_{1}$ families also were inoculated with UK $1 \pm P 3$ I153F. No $\mathrm{B}_{1} \mathrm{~S}_{1}$ plant became infected with UK $1 P 3 \mathrm{I} 153 \mathrm{~F}$, indicating that all plants possessed TuRBO1, TuRBO3, or both. Families identified above as segregating for the presence of TuRBO3 also showed segregation for resistance towards UK 1 (data not shown). UK 1 overcomes TuRBO3 resistance; therefore, the observed segregation was due to the presence of TuRB01. The results indicated that $\mathrm{B}_{1}$ plants lacking TuRBO3 were homozygous for TuRBO1, and that $\mathrm{B}_{1}$ plants heterozygous for TuRB03 also were heterozygous for TuRBO1. No families with other combinations of alleles were identified. This is consistent with TuRBO1 and TuRBO3 residing on the same chromosome (Hughes et al. in press).

\section{Natural mutations \\ at $\mathrm{P3}$ position 153 also overcome resistance.}

On four occasions, individual plants predicted to be resistant to infection developed symptoms. In each case, the identity of the virus was examined by sequencing. A $22 \mathrm{~S}$ plant inoculated with vVIR129, a UK 1 construct containing the CDN 1 P3 region (Fig. 1B), was found to be infected by a mutant (vVIR129M1). This virus possessed a single mutation at the nucleotide position $+2917(\mathrm{~T}>\mathrm{G})$ of the open reading frame, causing the alteration $P 3 \mathrm{~F} 153 \mathrm{~V}$ (Table 1). Two $\mathrm{B}_{1} \mathrm{~S}_{1}$ plants inoculated with UK $1 P 3$ I153F and a single 22S plant inoculated with UK 1 CI H630R P3 I153F also became infected, and sequence analysis confirmed that each virus had gained the identical mutation. No instances of spontaneous reversion ( $P 3$ F153I) or mutation to other amino acids enabling virulence towards TuRBO3 were observed.

\section{Other avirulence determinants.}

Mutation of the P3 amino acid 153 did not affect the outcome of UK 1 or CDN 1 challenges against B. napus lines (R4 and 165) possessing other resistance genes (data not shown).
However, the introduction of CDN 1 CI C-terminus into UK 1 (on the 1.2-kb BstEII-BstEII fragment) caused B. napus line R4 to be systemically infected (i.e., consistent with the TuRBO1determinant being in this region as found previously for the isolate UK 1) (Jenner et al. 2000). Similarly, any construct containing the $0.5-\mathrm{kb} 3^{\prime}$ region of CDN 1 P3 in a UK 1 background caused $B$. napus line 165 to produce local necrotic lesions, consistent with the TuRBO4-determinant being in this region as found previously for the isolates UK 1 and $\mathrm{CHN} 12$ (Jenner et al. 2002a).

The introduction of P3 F153I into CDN 1 caused B. napus line $22 \mathrm{~S}$ to be systemically infected without necrosis. Although UK 1 also possesses isoleucine at this position, the infection of line $22 \mathrm{~S}$ was necrotic. Enzyme-linked immunosorbent assay (ELISA) data (not shown) indicated that extensive viral replication occurred in plants infected with UK 1 despite the extensive necrosis. Therefore, isolate UK 1 possesses a determinant of necrosis that is absent from CDN 1 .

\section{TuMV P3 is a symptom severity determinant.}

The symptoms induced by CDN 1 on susceptible hosts such as $B$. juncea were much more pronounced and chlorotic than those induced by UK 1, particularly during periods of short daylight (Fig. 3). The introduction of the 0.9-kb Eco47III-BtgI fragment from CDN 1 into the UK 1 background (i.e., pVIR125; Fig. 1B) caused the typical CDN 1-like yellow mosaic symptoms. The $0.9-\mathrm{kb}$ CDN 1 fragment encoded 24 amino acid differences in the $\mathrm{P} 3$ protein $\mathrm{C}$-terminus, 2 differences in the $6 \mathrm{~K} 1$ protein and 3 differences in the $\mathrm{CI}$ protein compared with the UK 1 sequence. Replacement of the section encoding the $6 \mathrm{~K} 1$ and $\mathrm{CI}$ proteins with the original UK 1 sequence by overlap extension polymerase chain reaction (PCR) created pVIR156 (Fig. 1B). Virus derived from pVIR156 differed from UK 1 only in the P3 protein C-terminus. Virus derived from this construct induced the pronounced CDN 1-like symptoms on susceptible plants (Fig. 3).

\section{DISCUSSION}

We have shown that the TuMV P3 protein is the avirulence determinant for TuRBO3 and also affects symptom severity in susceptible plants. We also showed previously that P3 is the avirulence determinant for TuRB04 (Jenner et al. 2002a). Just as it has been noted that bacterial avirulence genes have roles in pathogenicity (Gabriel 1999; van't Slot and Knogge 2002), so it seems to be the case for TuMV. The small size of viral genomes generally means that most, if not all, of the encoded proteins have indispensable and multiple roles in the viral life

Table 1. Six P3 amino acid residues differing between Turnip mosaic virus isolates UK 1 and CDN 1 in the 0.4-kb BbsI-Eco47III fragment of pVIR136 and their effect on the phenotype of Brassica napus line $22 \mathrm{~S}$ plants

\begin{tabular}{|c|c|c|c|c|c|c|c|}
\hline \multirow[b]{2}{*}{ Virus } & \multicolumn{6}{|c|}{ Amino acid position in $\mathbf{P 3}^{\mathrm{a}}$} & \multirow[b]{2}{*}{ Plant symptoms ${ }^{\mathrm{b}}$} \\
\hline & 65 & 73 & 118 & 144 & 148 & 153 & \\
\hline UK 1 (v35Tunos) & $\mathrm{Y}$ & $\mathrm{V}$ & $\mathrm{V}$ & W & $\mathrm{D}$ & I & $t_{N}$ \\
\hline CDN 1 (vVIR95, 136) & $* \mathrm{H}$ & $* \mathrm{~A}$ & $*_{\mathrm{I}}$ & $* \mathrm{Y}$ & $* \mathrm{~N}$ & $* \mathrm{~F}$ & 0 \\
\hline UK $1 P 3 \mathrm{Y} 65 \mathrm{H}$ & $* \mathrm{H}$ & $\mathrm{V}$ & $\mathrm{V}$ & W & $\mathrm{D}$ & I & $+_{N}$ \\
\hline UK 1 P3 V73A & $\mathrm{Y}$ & $*_{\mathrm{A}}$ & $\mathrm{V}$ & W & $\mathrm{D}$ & I & $t_{N}$ \\
\hline UK $1 P 3$ V118I & $\mathrm{Y}$ & $\mathrm{V}$ & $* \mathrm{I}$ & W & $\mathrm{D}$ & I & $t^{4}$ \\
\hline UK 1 P3 W144Y & $\mathrm{Y}$ & $\mathrm{V}$ & $\mathrm{V}$ & $* \mathrm{Y}$ & $\mathrm{D}$ & I & $t_{N}$ \\
\hline UK $1 P 3$ D148N & $\mathrm{Y}$ & $\mathrm{V}$ & $\mathrm{V}$ & $\mathrm{W}$ & $* \mathrm{~N}$ & I & Mild $+_{N}$ \\
\hline UK $1 P 3 \mathrm{I} 153 \mathrm{~F}$ & $\mathrm{Y}$ & $\mathrm{V}$ & $\mathrm{V}$ & W & $\mathrm{D}$ & $* \mathrm{~F}$ & 0 \\
\hline CDN 1 P3 F153I & $* \mathrm{H}$ & $* \mathrm{~A}$ & $*_{\mathrm{I}}$ & $* \mathrm{Y}$ & $* \mathrm{~N}$ & I & + \\
\hline vVIR129 & $* \mathrm{H}$ & $* \mathrm{~A}$ & *I & $* \mathrm{Y}$ & $* \mathrm{~N}$ & $* \mathrm{~F}$ & 0 \\
\hline vVIR129M1 & $*^{*} \mathrm{H}$ & $* \mathrm{~A}$ & $* \mathrm{I}$ & $* \mathrm{Y}$ & $* \mathrm{~N}$ & V & Mild $+_{N}$ \\
\hline
\end{tabular}

${ }^{\mathrm{a}}$ Letters preceded by an asterisk (*) indicate residues corresponding to CDN 1.

${ }^{\mathrm{b}} 0=$ No symptoms observed, no viral replication detected by enzyme-linked immunosorbent assay; $+_{\mathrm{N}}=$ systemic necrotic infection; and $+=$ systemic nonnecrotic infection. 
cycle. The precise role of the $\mathrm{P} 3$ protein in the normal viral life cycle is not clear (Urcuqui-Inchima et al. 2001). Cleavage from the $6 \mathrm{~K} 1$ protein occurs only slowly (Merits et al. 2002) and may be the method of viral control of its activity (Riechmann et al. 1995). An involvement in replication is suspected (Klein et al. 1994; Rodríguez-Cerezo et al. 1993) because P3 is found with nuclear inclusion bodies (Langenberg and Zhang 1997) and is able to interact with proteins of the replication complex (Guo et al. 2001; Merits et al. 1999). Over-expression of P3 is known to produce deleterious effects on cell cycles (Rodríguez-Cerezo and Shaw 1991).

Segregation ratios in plants of the $B_{1}$ and $B_{1} S_{1}$ generations inoculated with TuMV CDN 1 suggested the presence of two dominant resistance genes. When a larger population of $B_{1}$

\section{TuMV isolate/ construct}

\section{UK 1}

\section{CDN 1}

\section{P3 amino acid 153}

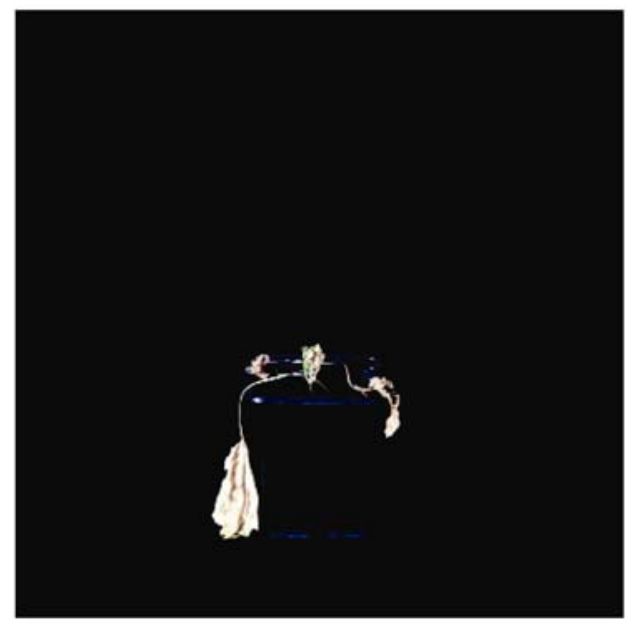

Ile
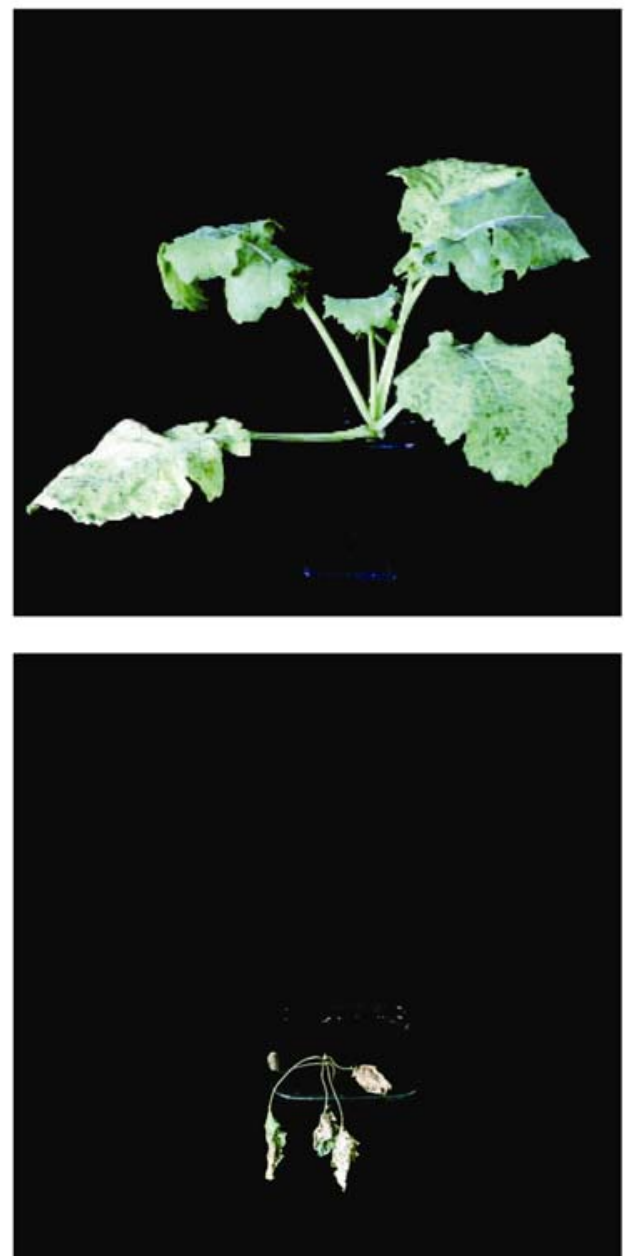

Phe
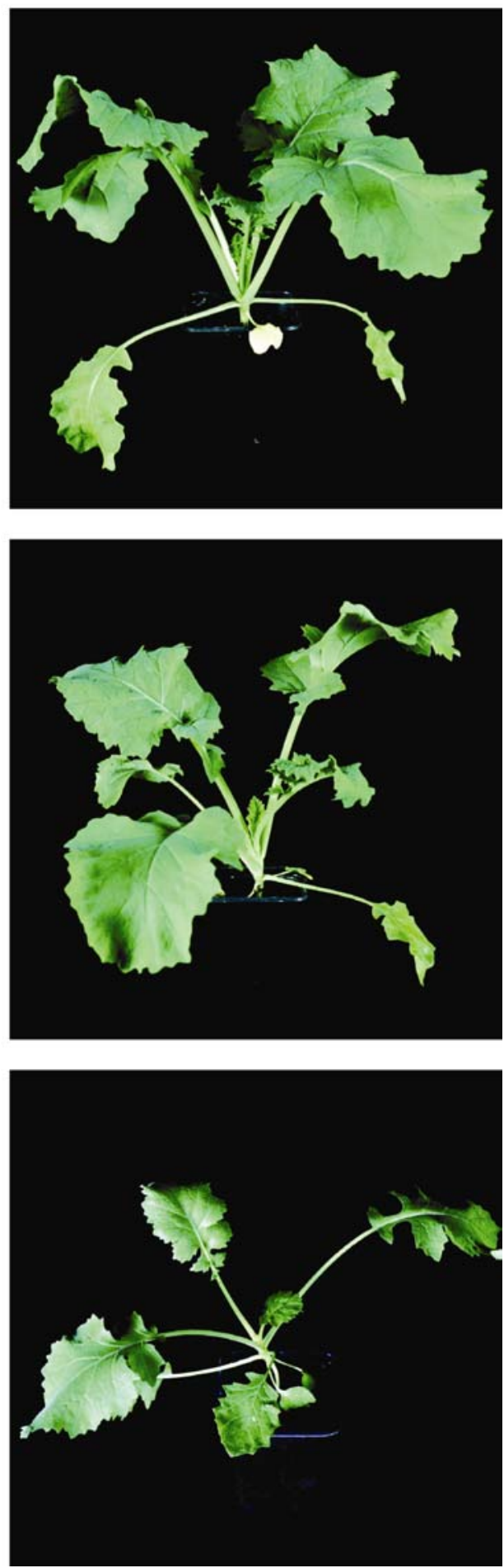

Fig. 2. Effect of identity of Turnip mosaic virus $\mathrm{P} 3$ amino acid 153 on the symptoms produced by Brassica napus line 22S. 
plants was tested, the segregation was consistent with a single dominant gene, TuRBO3 (Hughes et al. in press). The TuMV UK 1 construct that mimicked $C D N 1$ at $P 3$ position 153 showed the same segregation for the $\mathrm{B}_{1}$ generation as $\mathrm{CDN} 1$ but at a segregation ratio consistent with one gene in the $\mathrm{B}_{1} \mathrm{~S}_{1}$ generation. A single amino acid change in the CDN 1 P3 (F153I) resulted in all $\mathrm{B}_{1} \mathrm{~S}_{1}$ individuals being infected; therefore, if there is a second gene interacting with CDN 1, this suggests that it has the same mechanism of action as TuRBO3.

Our study has identified the C-terminal half (residues 182355) of the P3 protein of TuMV as a symptom severity determinant. This domain contained not only most of the variation in P3 amino acids between the two isolates studied, but also encompassed the avirulence determinant for the B. napus resistance gene TuRBO4 (Jenner et al. 2002a). Therefore, we have demonstrated a dual role for the potyviral P3 protein in both pathogenicity and recognition by the host resistance machinery. The C-terminal third of the $\mathrm{P} 3$ protein of another potyvirus, Tobacco etch virus, previously has been identified as being one of two components needed for a wilting response in tabasco pepper (Chu et al. 1997). The P3+6K1 region has also been identified as involved in host range for PPV (Dallot et al. 2001; Sáenz et al. 2000).

The P3 gene and protein are among the most variable in potyvirus genomes (Shukla et al. 1991). The extent of its varia- tion between potyvirus species, together with the examples of involvement of P3 in symptoms and host range within a species, may be an indication that this protein is critical to the host range and, hence, even the species designation or identity of any given potyvirus.

The P3+6K1 complex previously has been identified as critical to resistance controlled by the recessive gene sbm2 for PSbMV (Johansen et al. 2001). We now have shown that the $\mathrm{P} 3$ gene is involved in avirulence for the B. napus resistance genes TuRBO3 and TuRBO4 (Jenner et al. 2002a). It is tempting to consider that the mechanisms for each mode of resistance may be very different depending on whether controlled by a recessive or dominant resistance gene. Recessive gene resistance, if based on the lack of a plant factor required for viral replication, may be broad spectrum due to the fundamental requirement for P3 for viral pathogenicity. Dominant gene resistance based on recognition of specific motifs could be quite isolate specific due to the high amounts of sequence variation.

Viral mutations to overcome the resistance genes TuRBO4 and $T u R B 05$ are unstable in the absence of selection pressure (Jenner et al. 2002a). In contrast, mutations that overcome TuRBO1 are more stable but nonetheless have a slight cost to viral fitness (Jenner et al. 2002b). The mutations affecting P3 position 153 appeared to be stable in the absence of TuRBO3

Table 2. Ability of Turnip mosaic virus constructs to infect parental Brassica napus lines and families of selfed seed $\left(\mathrm{B}_{1} \mathrm{~S}_{1}\right)$ from the backcross $\mathrm{N}-\mathrm{o}-1 \times\left(\mathrm{F}_{1}\right.$ from $\mathrm{N}-\mathrm{o}-1 \times 22 \mathrm{~S})$

\begin{tabular}{|c|c|c|c|c|}
\hline \multirow[b]{3}{*}{ Brassica napus plant line } & \multicolumn{4}{|c|}{ Virus construct $^{\mathrm{a}}$} \\
\hline & \multicolumn{2}{|c|}{ CDN 1} & \multicolumn{2}{|c|}{ UK 1 CI H630R } \\
\hline & $(P 3153=F)$ & P3 F153I & $(P 3153=I)$ & P3 I153F \\
\hline $22 \mathrm{~S}$ & $0(8)$ & $+(8)$ & $+_{N}(8)$ & $0(8)$ \\
\hline $\mathrm{N}-\mathrm{o}-1$ & $+(8)$ & $+(8)$ & $t_{N}(8)$ & $+_{N}(8)$ \\
\hline $\mathrm{B}_{1} \mathrm{~S}_{1}$ families $1,2,5,6,7,8$ & $+(48)$ & $+(48)$ & $t_{N}(48)$ & $+_{N}(48)$ \\
\hline $\mathrm{B}_{1} \mathrm{~S}_{1}$ families $3,4,9,10,11,12,13,14,15,16,17,18,19,20$ & $0(94),+(18)$ & $+(112)$ & $+_{N}(112)$ & $0(78),+_{N}(34)$ \\
\hline
\end{tabular}

${ }^{\mathrm{a}} 0=$ No symptoms observed, no viral replication detected by enzyme-linked immunosorbent assay; $+_{\mathrm{N}}=$ systemic necrotic infection; $+=$ systemic nonnecrotic infection. Numbers of plants with phenotype in brackets.

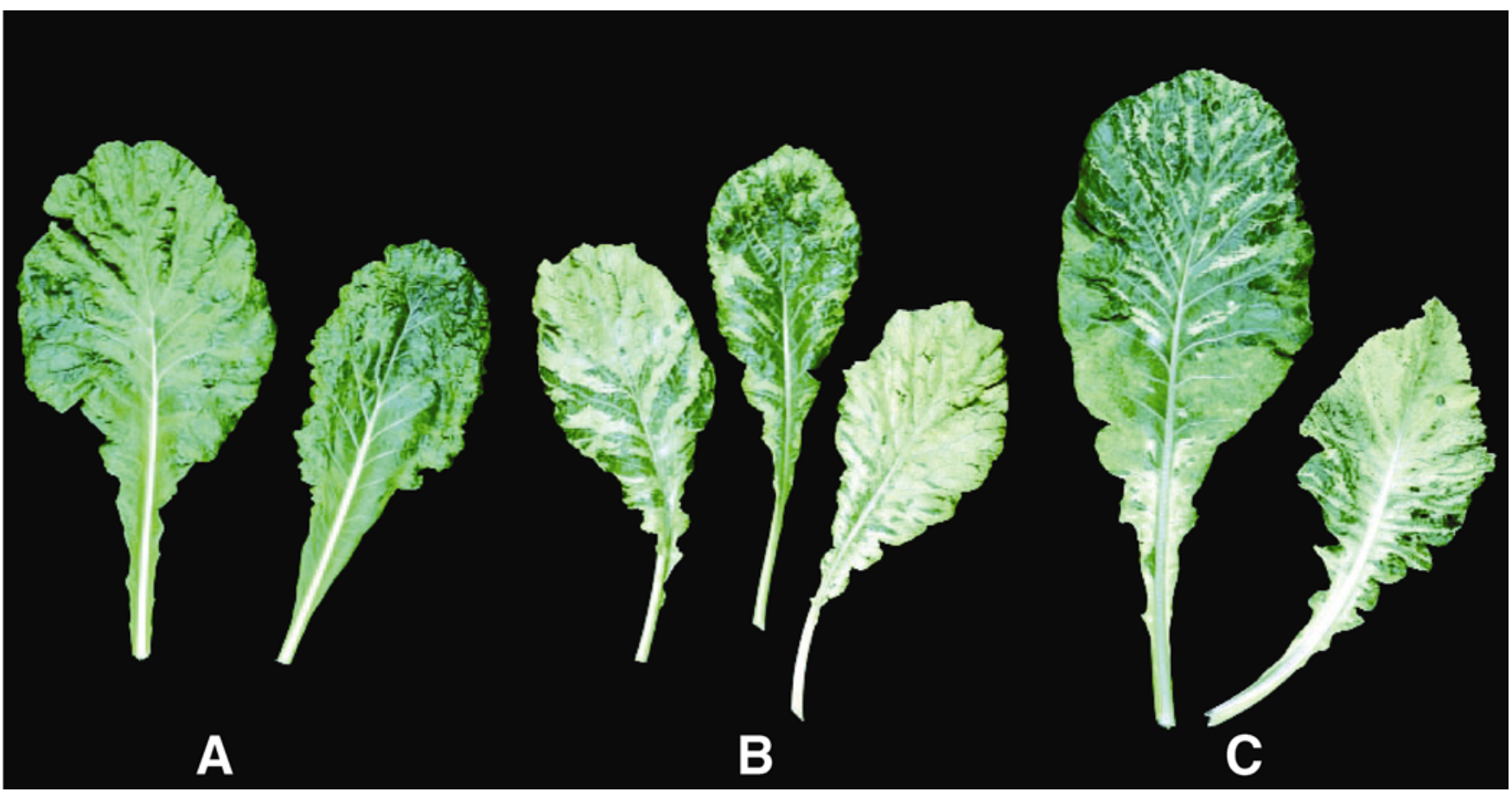

Fig. 3. Symptoms induced by Turnip mosaic virus isolates CDN 1 and UK 1 and the chimeric construct vVIR156 (UK 1 possessing the C-terminal half of CDN 1 P3) on the susceptible propagation host Brassica juncea cv. Tendergreen. A, UK 1; B, vVIR156; C, CDN 1. 
selection pressure, at least in the short term and in the different virus isolate backgrounds. The effect on viral fitness has not yet been examined.

We have now identified the viral avirulence factors involved in the interaction with four $B$. napus resistance genes. TuRBO3 is on the same chromosome as TuRBO1, but the two genes interact with different parts of the viral genome (P3 and CI, respectively). Both TuRBO3 and TuRBO4 interact directly or indirectly in some way with the $\mathrm{P} 3$ protein, whereas TuRBO1 and TuRBO5 interact with the CI protein: the TuMV avirulence determinants for brassica resistance genes appear to be clustering in the $\mathrm{P} 3 / \mathrm{CI}$ region of the viral genome. Our understanding of the basis of the B. napus pathotyping system (Walsh 1989) is increasing; however, as yet, we do not understand anything of the biochemical basis underlying the recognition processes.

\section{MATERIALS AND METHODS}

Virus isolates and plant lines.

The TuMV isolates UK 1 and CDN 1 have been described and characterized previously (Jenner and Walsh 1996). The isolate UK 1 was used to construct an infectious cDNA clone, p35Tunos (Sánchez et al. 1998), GenBank accession no. AF169561. All viruses were maintained by mechanical inoculation in B. juncea (mustard) cv. Tendergreen as described previously (Jenner and Walsh 1996).

The B. napus line $22 \mathrm{~S}$ is resistant to TuMV CDN 1 and is susceptible to UK 1. B. napus line $\mathrm{N}-\mathrm{o}-1$ is a doubled-haploid line derived from cv. Westar (Sharpe et al. 1995) and is resistant to TuMV UK 1 but susceptible to CDN 1 (Walsh et al. 1999) and v35Tunos $+5570 \mathrm{~A}>\mathrm{G}$ (CI H630R) (Jenner et al. 2000). The B. napus lines R4 and 165 were described previously (Walsh 1989).
B. napus line $\mathrm{N}-\mathrm{o}-1$ was crossed with line $22 \mathrm{~S}$ to generate $\mathrm{F}_{1}$ plants, then a single $\mathrm{F}_{1}$ plant was back-crossed to line N-o-1. In all, $20 \mathrm{~B}_{1}$ plants were self-pollinated to create $20 \mathrm{~B}_{1} \mathrm{~S}_{1}$ families. Each family was assessed for segregation of phenotypes by inoculation of eight plants with each viral construct as described previously (Jenner et al. 2002a).

\section{Molecular genetic techniques.}

Reverse-transcription (RT)-PCR was performed on virus in plants as described previously (Jenner et al. 2000). Sequences of plasmids and PCR products were obtained as described previously (Jenner et al. 2002a). Sequences of oligonucleotide primers used in this study are given in Table 3. Cloning and manipulation of plasmids were performed using standard molecular genetic techniques.

\section{Production of infectious clone of TuMV CDN 1.}

The Cauliflower mosaic virus 35S promoter region from p35Tunos was isolated by PCR using the primers T62 and T63. A cDNA copy of the $0.4 \mathrm{~kb}$ at the $5^{\prime}$ end of the CDN 1 genome was obtained from infected mustard leaf by RT-PCR using the primers T64 and T65. The two products were combined as the template for overlap extension PCR (Horton et al. 1989) with the primers T62 and T65. The resultant 1.1-kb hybrid product was cloned into pMOSBlue (Amersham, Little Chalfont, U.K.). A cDNA copy of the majority of the CDN 1 genome was obtained by immunocapture RT-PCR (Romero et al. 1997) using the TaqPlus Long PCR System (Stratagene, Cambridge, U.K.) with the primers Tu240 and Tu9669. The resultant 9.4-kb fragment was cloned into pCR2.1-TOPO (Invitrogen, Paisley, U.K.). RT-PCR using the primers $\mathrm{T} 1$ and $\mathrm{P} 3 \mathrm{~S}$ produced a cDNA copy of the $3^{\prime} 1.5 \mathrm{~kb}$ of the genome, which was cloned into pMOSBlue. The full-length infectious clone of CDN 1 (pVIR95) was produced by substitution of the three sections

Table 3. Oligonucleotide primers used in this study

\begin{tabular}{|c|c|c|}
\hline Name & Sequence $\left(5^{\prime}-3^{\prime}\right)^{\mathbf{a}}$ & Sense \\
\hline P3S & GCGTCGACTAGTACTCGAGTTTTTTTTTTT & - \\
\hline Tu240 & CCACCGTCACCACAGTCG & + \\
\hline Tu9669 & TATTTCCCATAAGCGAGAATACTAAC & - \\
\hline T1 & CTGGAACCTGAGCGAATAGTATCG & + \\
\hline T9 & GGTGGGACGTCCTTTGGTAAC & - \\
\hline T50 & GAGCTTGCGGATGGTGGATACA & + \\
\hline T51 & GCGCCTGCGACAACTGCT & - \\
\hline T62 & GCGCGTTGGCCGATTCAT & + \\
\hline T63 & CGTTTTGTGTATGTTGTGTTGAGTTTTAT & - \\
\hline T64 & ATAAAAACTCAACACAACATACACAAAAC & + \\
\hline T65 & GCATCCTCAACACGGCACTC & - \\
\hline $\mathrm{T} 78$ & TGCGTAACAACAGAGTCAGGAGAT & + \\
\hline $\mathrm{T} 79$ & ACTTCCGTGGCTGTTGCTCTGG & - \\
\hline T80 & ACAGCCACGGAAGTAGCGGGCAAG & + \\
\hline T81 & TTGAGGTTACCGTTTTGAAGTACT & - \\
\hline T82 & AACGGTAACCTCAAATTGTGTTTC & + \\
\hline $\mathrm{T} 83$ & GTGGCTCTCTAGAGCACTTGATGAACCATTACATC & + \\
\hline T84 & GATGTAATGGTTCATCAAGTGCTCTAGAGAGCCAC & - \\
\hline T85 & CCATTACATCAGGGCGGACAGCAACGTCG & + \\
\hline T86 & CGACGTTGCTGTCCGCCCTGATGTAATGG & - \\
\hline T87 & CGAAGCAAAGGCTAATATTAATGGGCCAGATGACG & + \\
\hline T88 & CGTCATCTGGCCCATTĀATATTAGCCTTTGCTTCG & - \\
\hline T89 & GGCAGAACCAAACTATGAGCTTGCGGATGGTGGATAC & + \\
\hline T90 & GTATCCACCATCCGCAAGCTCATAGTTTGGTTCTGCC & - \\
\hline T91 & CCAAACTGGGAGCTTGCGAATGGTGGATACAC & + \\
\hline T92 & GTGTATCCACCATICGCAĀGCTCCCAGTTTGG & - \\
\hline T93 & GGATGGTGGATACACATTTCTGAGGGATCATAGC & + \\
\hline T94 & GCTATGATCCCTCAGAAATGTGTATCCACCATCC & - \\
\hline T95 & GATTGTCTCTTAGCTTGGTGGACT & - \\
\hline T96 & CAAGCTAAGAGACAATCCGAGCAAGAAC & + \\
\hline T97 & CGAACGGCGGATATACAATTCTGAGAGATCACAG & + \\
\hline T98 & CTGTGATCTCTCAGAATTGTATATCCGCCGTTCG & - \\
\hline
\end{tabular}

${ }^{a}$ Underlined base indicates introduction of mutation and italicized bases indicate introduction of a restriction enzyme site. 
into p35Tunos: a 0.7-kb SmaI-PpuMI fragment (35S promoter and $5^{\prime}$ end of viral genome), a 8.2-kb PpuMI-MluI fragment (main section), and a $1.3 \mathrm{~kb}$ MluI-SalI fragment ( $3^{\prime}$ end).

The CDN 1 virus and plasmid pVIR95 were sequenced (GenBank accession nos. AB093610 and AY227024, respectively) as above. Virus derived from the plasmid construct behaved in an identical manner to the original isolate CDN 1 on the $B$. napus lines.

\section{Construction of chimeric viruses.}

Each of the three segments used in the production of pVIR95 was exchanged individually with the corresponding region in p35Tunos. The main 8.2-kb section was divided using conserved restriction enzyme sites to make reciprocal exchanges between p35Tunos and pVIR95 of the 1.8-kb PpuMI-XcmI, 4.6-kb XcmIBstEII, and 1.8-kb BstEII-MluI fragments (Fig. 1A).

The 4.6-kb XcmI-BstEII section of pVIR95 (present in pVIR112; Fig. 1B) was divided further by the introduction of a BtgI and an internal BstEII site corresponding to sites in the p35Tunos sequence. This was achieved by PCR using primers containing the novel sites (T78 with T79, T80 with T81, and T82 with T9), followed by cloning into pMOSBlue. Exchanges then were made using the resultant $1.9-\mathrm{kb} X c m \mathrm{I}-B t g \mathrm{I}, 1.5-\mathrm{kb}$ BtgI-BstEII, and 1.2-kb BstEII-BstEII fragments.

The 1.9-kb XcmI-BtgI section of pVIR95 (present in pVIR117) was manipulated further in subclones before being returned to the full-length plasmid. A 0.4-kb XcmI-Bst98I fragment was replaced by the corresponding UK 1 fragment without affecting the $22 \mathrm{~S}$ phenotype (pVIR121). The $1.5-\mathrm{kb}$ Bst98I-BtgI fragment of pVIR121 was dissected further by the replacement of either the $0.6-\mathrm{kb} B s t 98 \mathrm{I}-E c 047 \mathrm{III}$ or the $0.9-\mathrm{kb}$ Eco47III-BtgI portions by the corresponding UK 1 fragments to create pVIR124 and pVIR125.

The 0.6-kb Bst98I-Eco47III fragment of pVIR124 was split by the replacement of the 0.2-kb Bst98I-BbsI and 0.4-kb BbsIEco47III segments by the equivalent UK 1 fragments, creating pVIR135 and pVIR136.

The 0.9-kb Eco47III-BtgI fragment of pVIR125 was subdivided by overlap extension PCR using the primers T50 with T95 on pVIR125, the primers T96 with T51 on p35Tunos, and then the primers T50 with T51 on a mix of the two previous products, to create pVIR156.

Site-directed mutagenesis was performed on subclones of the UK 1 and CDN 1 genomes using the Stratagene QuikChange mutagenesis kit according to the manufacturer's instructions. Each codon was altered with the minimum of nucleotide substitutions to achieve the desired amino acid. In the case of introducing CDN 1 amino acid residues into UK 1, this entailed three of the six codons not matching the original CDN 1 codon due to redundancy in the third position of the codons. The alterations Y65H, V73A, V118I, W144Y, D148N, and I153F were achieved using the oligonucleotide combinations T83T84, T85-T86, T87-T88, T89-T90, T91-T92, and T93-T94, respectively. The only UK 1 amino acid change engineered into the CDN $1 \mathrm{P} 3$ protein, F153I, was achieved using the oligonucleotide combination T97-T98.

Plasmid DNA was purified by alkaline lysis followed by passage through a QIAGEN-tip 100 (Qiagen, Crawley, U.K.). Mustard plants were dusted with Carborundum, and then $10 \mu \mathrm{g}$ of plasmid was rubbed onto each plant to produce viral infection. Infectious plasmid constructs are denoted using the prefix $\mathrm{p}$; virus derived from infection of plants with these plasmids is designated with the prefix $\mathrm{v}$.

\section{Assessment of infection of plants.}

B. napus plants were mechanically inoculated as described previously (Jenner and Walsh 1996). Symptoms were assessed visually for 4 weeks. Presence of TuMV was verified by platetrapped antigen ELISA as described previously (Jenner et al. 2000) using the monoclonal antibody EMA67 (Jenner et al. 1999). The identity of virus present, and in particular the presence of introduced mutations, was verified by RT-PCR and sequencing of the appropriate part of the genome.

\section{ACKNOWLEDGMENTS}

This work was funded by the BBSRC Competitive Strategic Grant to Horticulture Research International, DEFRA (U.K.) and the EC (INCODC project ERB 3514 PL96 1223). X. Wang was funded by an AECI (Spanish Agency for International Cooperation) fellowship. The recombinant constructs were prepared and held in the U.K. under DEFRA licenses PHL 5F/3418, 5G/3775, and 166A/4122. We thank F. Sánchez for the gift of the infectious clone p35Tunos; S. Hughes for $\mathrm{B}_{1}$ seed; V. Shattuck for the TuMV isolate CDN 1; and J. Bambridge, R. Edwards, and S. Stevenson for technical assistance.

\section{LITERATURE CITED}

Bateson, M. F., Henderson, J., Chaleeprom, W., Gibbs, A. J., and Dale, J. L. 1994. Papaya ringspot potyvirus: Isolate variability and the origin of PRSV type P (Australia). J. Gen. Virol. 75:3547-3553.

Chu, M., Lopez-Moya, J. J., Llave-Correas, C., and Pirone, T. P. 1997. Two separate regions in the genome of the tobacco etch virus contain determinants of the wilting response of tabasco pepper. Mol. PlantMicrobe Interact. 10:472-480.

Dallot, S., Quiot-Douine, L., Sáenz, P., Cervera, M. T., García, J. A., and Quiot, J.-B. 2001. Identification of Plum pox virus determinants implicated in specific interactions with different Prunus spp. Phytopathology 91:159-164.

Fellers, J. P., Tremblay, D., Handest, M. F., and Lommel, S. A. 2002. The Potato virus $Y$ MSNR NIb-replicase is the elicitor of a veinal necrosishypersensitive response in root knot nematode resistant tobacco. Mol. Plant Pathol. 3:145-152.

Gabriel, D. W. 1999. Why do pathogens carry avirulence genes? Physiol. Mol. Plant Pathol. 55:205-214.

Glasa, M., Marie-Jeanne, V., Moury, B., Kúdela, O., and Quiot, J.-B. 2002. Molecular variability of the P3-6K1 genomic region among geographically and biologically distinct isolates of Plum pox virus. Arch. Virol. 147:563-575.

Guo, D., Rajamäki, M.-L., Saarma, M., and Valkonen, J. P. T. 2001. Towards a protein interaction map of potyviruses: Protein interaction matrixes of two potyviruses based on the yeast two-hybrid system. J. Gen. Virol. 82:935-939.

Horton, R. M., Hunt, H. D., Ho, S. N., Pullen, J. K., and Pease, L. R. 1989. Engineering hybrid genes without the use of restriction enzymes: Gene splicing by overlap extension. Gene 77:61-68.

Hughes, S. L., Green, S. K., Lydiate, D. J., and Walsh, J. A. 2002. Resistance to Turnip mosaic virus in Brassica rapa and B. napus and the analysis of genetic inheritance in selected lines. Plant Pathol. 51:567-573.

Hughes, S. L., Hunter, P. J., Sharpe, A. G., Kearsey, M. J., Lydiate, D. J., and Walsh, J. A. Genetic mapping of the novel Turnip mosaic virus resistance gene TuRB03 in Brassica napus. Theor. Appl. Genet. In press.

Jenner, C. E., Keane, G. J., Jones, J. E., and Walsh, J. A. 1999. Serotypic variation in turnip mosaic virus. Plant Pathol. 48:101-108.

Jenner, C. E., Sánchez, F., Nettleship, S. B., Foster, G. D., Ponz, F., and Walsh, J. A. 2000. The cylindrical inclusion gene of Turnip mosaic virus encodes a pathogenic determinant to the brassica resistance gene TuRB01. Mol. Plant-Microbe Interact. 13:1102-1108.

Jenner, C. E., Tomimura, K., Ohshima, K., Hughes, S. L., and Walsh, J. A. 2002a. Mutations in Turnip mosaic virus P3 and cylindrical inclusion proteins are separately required to overcome two Brassica napus resistance genes. Virology 300:50-59.

Jenner, C. E., and Walsh, J. A. 1996. Pathotypic variation in turnip mosaic virus with special reference to European isolates. Plant Pathol. 45:848-856.

Jenner, C. E., Wang, X., Ponz, F., and Walsh, J. A. 2002b. A fitness cost for Turnip mosaic virus to overcome host resistance. Virus Res. 86:1-6.

Johansen, I. E., Lund, O. S., Hjulsager, C. K., and Laursen, J. 2001. Recessive resistance in Pisum sativum and potyvirus pathotype resolved in a gene-for-cistron correspondence between host and virus. J. Virol. 75:6609-6614.

Keller, K. E., Johansen, I. E., Martin, R. R., and Hampton, R. O. 1998. Potyvirus genome-linked protein (VPg) determines pea seed-borne mosaic virus pathotype-specific virulence in Pisum sativum. Mol. Plant-Microbe Interact. 11:124-130. 
Klein, P. G., Klein, R. R., Rodríguez-Cerezo, E., Hunt, A. G., and Shaw, J. G. 1994. Mutational analysis of the tobacco vein mottling virus genome. Virology 204:759-769.

Krause-Sakate, R., Le Gall, O., Fakhfakh, H., Peypelut, M., Marrakchi, M., Varveri, C., Pavan, M. A., Souche, S., Lot, H., Zerbini, M., and Candresse, T. 2002. Molecular and biological characterization of Lettuce mosaic virus (LMV) isolates reveals a distinct and widespread type of resistance-breaking isolate: LMV-Most. Phytopathology 92:563-572.

Laín, S., Riechmann, J. L., and García, J. A. 1990. RNA helicase-a novel activity associated with a protein encoded by a positive strand RNA virus. Nucleic Acids Res. 18:7003-7006.

Langenberg, W. G., and Zhang, L. 1997. Immunocytology shows the presence of tobacco etch virus P3 protein in nuclear inclusions. J. Struct. Biol. 118:243-247.

Lehmann, P., Petrzik, K., Jenner, C., Greenland, A., Špak, J., Kozubek, E., and Walsh, J. A. 1997. Nucleotide and amino acid variation in the coat protein coding region of turnip mosaic virus isolates and possible involvement in the interaction with the brassica resistance gene TuRB01. Physiol. Mol. Plant Pathol. 51:195-208.

Masuta, C., Nishimura, M., Morishita, H., and Hataya, T. 1999. A single amino acid change in viral genome-associated protein of potato virus Y correlates with resistance breaking in 'Virgin A mutant' tobacco. Phytopathology 89:118-123.

Merits, A., Guo, D., Järvekülg, L., and Saarma, M. 1999. Biochemical and genetic evidence for interactions between potato A potyvirusencoded proteins $\mathrm{P} 1$ and $\mathrm{P} 3$ and proteins of the putative replication complex. Virology 263:15-22.

Merits, A., Rajamäki, M.-L., Lindholm, P., Runeberg-Roos, P., Kekarainen, T., Puustinen, P., Mäkeläinen, K., Valkonen, J. P. T., and Saarma, M. 2002. Proteolytic processing of potyviral proteins and polyprotein processing intermediates in insect and plant cells. J. Gen. Virol. 83:1211-1221.

Mestre, P., Brigneti, G., and Baulcombe, D. C. 2000. An Ry-mediated resistance response in potato requires the intact active site of the NIa proteinase from potato virus Y. Plant J. 23:653-661.

Nicolas, O., Dunnington, S. W., Gotow, L. F., Pirone, T. P., and Hellmann, G. M. 1997. Variations in the VPg protein allow a potyvirus to overcome va gene resistance in tobacco. Virology 237:452-459.

Ohshima, K., Yamaguchi, Y., Hirota, R., Hamamoto, T., Tomimura, K., Tan, Z., Sano, T., Azuhata, F., Walsh, J. A., Fletcher, J., Chen, J., Gera, A., and Gibbs, A. 2002. Molecular evolution of Turnip mosaic virus: Evidence of host adaptation, genetic recombination and geographical spread. J. Gen. Virol. 83:1511-1521.

Provvidenti, R. 1980. Evaluation of Chinese cabbage cultivars from Japan and the People's Republic of China for resistance to turnip mosaic virus and cauliflower mosaic virus. J. Am. Soc. Hortic. Sci. 105:571-573.

Revers, F., Le Gall, O., Candresse, T., and Maule, A. J. 1999. New advances in understanding the molecular biology of plant/potyvirus interactions. Mol. Plant-Microbe Interact. 12:367-376.

Riechmann, J. L., Cervera, M. T., and García, J. A. 1995. Processing of the plum pox virus polyprotein at the P3-6K1 junction is not required for virus viability. J. Gen. Virol. 76:951-956.

Robbins, M. A., Witsenboer, H., Michelmore, R. W., Laliberté, J.-F., and Fortin, M. G. 1994. Genetic mapping of turnip mosaic virus resistance in Lactuca sativa. Theor. Appl. Genet. 89:583-589.

Rodríguez-Cerezo, E., Ammar, E. D., Pirone, T. P., and Shaw, J. G. 1993. Association of the nonstructural P3 viral protein with cylindrical inclusions in potyvirus-infected cells. J. Gen. Virol. 74:1945-1949.

Rodríguez-Cerezo, E., and Shaw, J. G. 1991. Two newly detected nonstructural viral proteins in potyvirus-infected cells. Virology 185:572579.

Romero, A., Blanco-Urgoiti, B., and Ponz, F. 1997. Amplification and cloning of a long RNA virus genome using immunocapture-long-RTPCR. J. Virol. Methods 66:159-163.

Sáenz, P., Cervera, M. T., Dallot, S., Quiot, L., Quiot, J.-B., Riechmann, J. L., and García, J. A. 2000. Identification of a pathogenicity determinant of Plum pox virus in the sequence encoding the C-terminal region of protein P3+6K1. J. Gen. Virol. 81:557-566.

Sánchez, F., Martínez-Herrera, D., Aguilar, I., and Ponz, F. 1998. Infectivity of turnip mosaic potyvirus cDNA clones and transcripts on the systemic host Arabidopsis thaliana and local lesion hosts. Virus Res. 55:207-219.

Sharpe, A. G., Parkin, I. A. P., Keith, D. J., and Lydiate, D. J. 1995. Frequent non-reciprocal translocations in the amphidiploid genome of oilseed rape (Brassica napus). Genome 38:1112-1121.

Shattuck, V. I. 1992. The biology, epidemiology, and control of turnip mosaic virus. Plant Breed. Rev. 14:199-238.

Shukla, D. D., Frenkel, M. J., and Ward, C. W. 1991. Structure and function of the potyvirus genome with special reference to the coat protein coding region. Can. J. Plant Pathol. 13:178-191.

Shukla, D. D., Ward, C. W., and Brunt, A. A. 1994. The Potyviridae. CAB International, Wallingford, U.K.

Tomimura, K., Gibbs, A. J., Jenner, C. E., Walsh, J. A., and Ohshima, K. 2003. The phylogeny of Turnip mosaic virus; comparisons of thirtyeight genomic sequences reveal a Eurasian origin and a recent 'emergence' in east Asia. Mol. Ecol. 12:2099-2112.

Tomlinson, J. A. 1987. Epidemiology and control of virus diseases of vegetables. Ann. Appl. Biol. 110:661-681.

Ullah, Z., and Grumet, R. 2002. Localization of Zucchini yellow mosaic virus to the veinal regions and role of viral coat protein in veinal chlorosis conditioned by the zym potyvirus resistance locus in cucumber Physiol. Mol. Plant Pathol. 60:79-89.

Urcuqui-Inchima, S., Haenni, A.-L., and Bernardi, F. 2001. Potyvirus proteins: A wealth of functions. Virus Res. 74:157-175.

van't Slot, K. A. E., and Knogge, W. 2002. A dual role for microbial pathogen-derived effector proteins in plant disease and resistance. Crit. Rev. Plant Sci. 21:229-271.

Walsh, J. A. 1989. Genetic control of immunity to turnip mosaic virus in winter oilseed rape (Brassica napus ssp. oleifera) and the effect of foreign isolates of the virus. Ann. Appl. Biol. 115:89-99.

Walsh, J. A., and Jenner, C. E. 2002. Turnip mosaic virus and the quest for durable resistance. Mol. Plant Pathol. 3:289-300.

Walsh, J. A., Rusholme, R. L., Hughes, S. L., Jenner, C. E., Bambridge, J. M., Lydiate, D. J., and Green, S. K. 2002. Different classes of resistance to turnip mosaic virus in Brassica rapa. Eur. J. Plant Pathol. 108:15-20.

Walsh, J. A., Sharpe, A. G., Jenner, C. E., and Lydiate, D. J. 1999. Characterization of resistance to turnip mosaic virus in oilseed rape (Brassica napus) and genetic mapping of TuRB01. Theor. Appl. Genet. 99:1149-1154. 